\title{
Early Endosomal Abnormalities and Cholinergic Neuron Degeneration in Amyloid- $\beta$ Protein Precursor Transgenic Mice
}

\author{
Jennifer H.K. Choi ${ }^{\mathrm{a}, \mathrm{c}, 1,2}$, Gurjinder Kaur ${ }^{\mathrm{a}, 1}$, Matthew J. Mazzella ${ }^{\mathrm{a}}$, Jose Morales-Corraliza ${ }^{\mathrm{a}, \mathrm{b}}$, \\ Efrat Levy $y^{\mathrm{a}, \mathrm{b}, \mathrm{d}, *}$ and Paul M. Mathews ${ }^{\mathrm{a}, \mathrm{b}, *}$ \\ ${ }^{a}$ Nathan S. Kline Institute, Orangeburg, NY, USA \\ ${ }^{\mathrm{b}}$ Department of Psychiatry, NYU Langone School of Medicine, New York, NY, USA \\ ${ }^{\mathrm{c}}$ Department of Physiology and Neuroscience, NYU Langone School of Medicine, New York, NY, USA \\ ${ }^{\mathrm{d}}$ Department of Biochemistry and Molecular Pharmacology, NYU Langone School of Medicine, New York, NY, USA
}

Accepted 26 November 2012

\begin{abstract}
Early endosomal changes, a prominent pathology in neurons early in Alzheimer's disease, also occur in neurons and peripheral tissues in Down syndrome. While in Down syndrome models increased amyloid- $\beta$ protein precursor (A $\beta P P)$ expression is known to be a necessary contributor on the trisomic background to this early endosomal pathology, increased A $\beta P P$ alone has yet to be shown to be sufficient to drive early endosomal alterations in neurons. Comparing two A $\beta P P$ transgenic mouse models, one that contains the A $3 P P$ Swedish K670N/M671L double mutation at the $\beta$-cleavage site (APP23) and one that has the AßPP London V717I mutation near the $\gamma$-cleavage site (APPLd2), we show significantly altered early endosome morphology in fronto-parietal neurons as well as enlargement of early endosomes in basal forebrain cholinergic neurons of the medial septal nucleus in the APP23 model, which has the higher levels of A $\beta$ PP $\beta$-C-terminal fragment $(\beta C T F)$ accumulation. Early endosomal changes correlate with a marked loss of the cholinergic population, which is consistent with the known dependence of the large projection cholinergic cells on endosome-mediated retrograde neurotrophic transport. Our findings support the idea that increased expression of $\mathrm{A} \beta \mathrm{PP}$ and $\mathrm{A} \beta \mathrm{PP}$ metabolites in neurons is sufficient to drive early endosomal abnormalities in vivo, and that disruption of the endocytic system is likely to contribute to basal forebrain cholinergic vulnerability.
\end{abstract}

Keywords: Alzheimer's disease, amyloid- $\beta$ protein precursor, cholinergic neurons, endocytosis, endosomes, septal nuclei

\section{INTRODUCTION}

Neuronal early endosome alterations occur early in Alzheimer's disease (AD), preceding amyloid- $\beta(\mathrm{A} \beta)$

\footnotetext{
${ }^{1}$ These authors contributed equally to this work.

${ }^{2}$ Current affiliation: Department of Biology, University of Pennsylvania Perelman School of Medicine, Philadelphia, PA, USA

*Correspondence to: Paul M. Mathews and Efrat Levy, Nathan S. Kline Institute, Center for Dementia Research, 140 Old Orangeburg Rd, Bldg 39, Orangeburg, NY 10962, USA. Tel.: +1 845398 5428; Fax: +1 845398 5422; E-mail: mathews@nki.rfmh.org or E-mail: elevy@nki.rfmh.org.
}

accumulation in the frontal cortex and robust neurofibrillary tangle pathology [1]. While the etiology of AD-related neuronal early endosomal dysfunction is likely to be complex, dependent in part upon lipid metabolism [2-4], apolipoprotein E allelic variation [1] as well as other genetic risk factors [5], growing evidence suggests that amyloid- $\beta$ protein precursor (A $\beta P P)$ levels and the levels of specific A $\beta P P$ metabolites may contribute to endosomal disruption in neurons [6] and non-neuronal cells [7]. In human Down syndrome (DS), in which the gene for App is triplicated, neuronal early endosomal changes similar to those seen in $\mathrm{AD}$ occur decades prior to $\mathrm{A} \beta$ pathology 
[1], and are additionally seen in non-neuronal cells such as cultured DS fibroblasts [8]. In the DS mouse model Ts65Dn, neuronal early endocytic morphological disruption is dependent upon App gene triplication, arguing that increased A $\beta P P$ expression is necessary for early endosomal disruption in the context of DS trisomy [6]. Recently, we and our colleagues have shown that A $\beta P P$ overexpression, and in particular the overexpression of the $\beta$-cleavage-generated C-terminal fragment ( $\beta \mathrm{CTF}$ ) of $\mathrm{A} \beta \mathrm{PP}$, is necessary for the manifestation of early endosomal changes in cultured DS fibroblasts [7]. Consistent with the idea that A $\beta P P$ overexpression itself can lead to early endosomal disruption, increased expression in the cortex of endocytic proteins, such as clathrin and dynamin, has been reported in the A $\beta P P$-overexpressing Tg2576 mouse, although early endosome morphology was not directly examined [9]. In our study, we set out to examine endosomes in two mouse models with A $\beta P P$ overexpression, the APP23 mouse model that has the A $\beta P P$ Swedish K670N/M671L double mutation at the $\beta$-cleavage site resulting in increased production of $\beta C T F s$, and the APPLd2 mouse model that has the A $\beta P P$ London V717I mutation near the $\gamma$-cleavage site, resulting in increased $A \beta_{42}$ production [10-12].

Basal forebrain cholinergic neurons (BFCNs) are a widely examined neuronal subpopulation that are dependent upon early endosome-mediated signaling $[13,14]$ and are particularly vulnerable to degeneration in AD [15-19]. These neurons, with long axonal projections to distal sites, are dependent on proper endosome function to deliver critical nerve growth factor retrograde trophic-support via signaling endosomes from the axon terminus to the cell soma [14, 20-22]. In addition to deficient neurotrophic factor signaling leading to neurodegeneration, altered early endocytic function in neurons is likely to have multiple pathological consequences for the cell [23, 24], including disruption of A $\beta P P$ metabolism [25].

Mouse models of A $\beta P P$ overexpression and $A \beta$ accumulation typically show some levels of BFCN changes. There are prior reports of cholinergic fiber loss and distortion in APP23 mice [26] and in APPLd2 mice [27]. Previous studies have also reported smaller BFCN cell bodies in APP23 medial septal nucleus (MSN) [26], consistent with cholinergic system impairment in APP23 mice as demonstrated by reduced acetylcholinesterase and choline acetyltransferase (ChAT) enzyme activity [26, 28]. These changes in BFCN morphology and cholinergic biochemistry have not yet been shown to be associated with the endocytic system changes, nor has endosome morphology been characterized in these A $\beta P P$ overexpression mouse models. Thus, we set out to characterize these systems in the APP23 and APPLd2 mice.

\section{MATERIALS AND METHODS}

\section{Animals}

All mouse experimentation and animal care was conducted in accordance to protocols approved by the Nathan S. Kline Institute's Institutional Animal Care and Use Committee. APPLd 2 mice $(n=15)$ and APP23 mice $(n=14)$ were maintained on a $\mathrm{C} 57 \mathrm{BL} / 6 \mathrm{~J}$ background, and wild-type (wt) littermates of both lines $(n=16)$ were used as control animals. Animals of both sexes ranging in age 12-14 months were used in this study.

\section{Immunolabeling and antibodies}

For all immunohistological procedures, mice were anesthetized with ketamine $(50 \mathrm{mg} / \mathrm{kg}) / \mathrm{xylazine}$ $(5 \mathrm{mg} / \mathrm{kg})$ and transcardially perfusion-fixed with $4 \%$ paraformaldehyde in $0.1 \mathrm{M}$ sodium cacodylate buffer. Brains were removed and post-fixed overnight in $4 \%$ paraformaldehyde in phosphate buffered saline (PBS) at $4{ }^{\circ} \mathrm{C}$, transferred to PBS the next day, and subsequently cut into $40 \mu \mathrm{m}$-thick coronal sections with a vibratome. Free-floating sections from all the mouse groups were concurrently processed for immunohistochemical examination [29]. Control sections were processed with the omission of the primary or secondary antibodies to exclude non-specific reactions.

Using goat polyclonal antibodies, fluorescent labeling was performed to label rab5b (sc-26569; Santa Cruz Biotechnology, Santa Cruz, CA; dilution $1: 100$ ) or rabaptin-5 (sc-6162; Santa Cruz Biotechnology, Santa Cruz, CA; dilution $1: 100$ ). Double immunofluorescence labeling was performed to identify coincidence of $\mathrm{A} \beta \mathrm{PP}$ and ChAT using either monoclonal anti-A $\beta P P / \beta C T F / A \beta$ antibody 6E10 (SIG-39320; Convance ImmunoTechnologies, Denver, PA; dilution $1: 200)$ or monoclonal antibody C1/6.1 $(1 \mu \mathrm{g} / \mathrm{ml}$, which recognizes the carboxyl-terminal cytoplasmic domain of AßPP [25]) with goat polyclonal antiChAT antibody (AB144P; EMD Millipore, Billerica, MA; dilution $1: 500$ ). ChAT colocalization with rab5b was determined by dual immunostaining using rabbit anti-ChAT (AB143; EMD Millipore, Billerica, MA; dilution $1: 500$ ) and the earlier described goat anti-rab5b antibody. Following binding of fluorophoreconjugated secondary antibody (Invitrogen, Grand 
Island, NY; dilution $1: 500$ ), immunofluorescence was observed and captured at $100 \times$ magnification using an LSM 510 Meta confocal microscope (Zeiss, Thornwood, NY). In total, approximately 30 neurons per animal were measured ( $n=4$ per genotype) randomly by a genotype-blinded observer. Appropriate anatomical regions were identified at low-power magnification by a blinded observer. Switching to the $100 \times$ objective, the center-field neuron(s) were analyzed. Each neuron sampled was at least two cell-lengths from the closest sampled neuron, and neurons from several sections throughout the region were analyzed, totaling 10-12 neurons from 3 brain sections per animal. Quantitation of rab5b signal was measured using Image $(\mathrm{NIH}$, USA) after thresholding the density of rab5b-positive signal over background; the average endosomal size was calculated as the ratio of positive-pixels per rab5 positive endosomes in a neuron to the number of endosomes in the neuron.

For stereological counting of ChAT neurons, diaminobenzidine (DAB) staining was employed. Following incubation in anti-ChAT (AB144P) primary antibody, sections were washed in diluting buffer and treated with biotinylated rabbit anti-sheep IgG antibody (Vector Laboratories, Burlingame, CA; 1 : 500), and developed using the avidin-biotin-peroxidase solution (ABC kit, Vector Laboratories, Burlingame, CA) and DAB (Sigma, St. Louis, MO).

\section{Optical fractionator procedure}

The optical fractionator system consisted of a computer assisted image analysis system including a Zeiss Axioskop II microscope hard-coupled to an Applied Scientific Instrumentation MS-2000 computer controlled $x-y-z$ motorized stage, a Qimaging Qicam Fast 1394 color camera, a Dell Optiflex 755 computer, and Bioquant Life Science stereological software (Bioquant Image Analysis, Nashville, TN). Stereological cell counting was conducted as previously described by Granholm et al. [30]. The MSN was outlined under a low magnification $(2.5 \times)$ using the following landmarks: The rostral border consisted of the medial orbital cortex (at the level of the midline fusion of the corpus callosum), the caudal border consisted of the midline fusion of the anterior commissure, and the lateral borders consisted of the shell of the Accumbens nucleus. The outlined region was overlaid by a systematic random design of dissector counting frames $(100 \times 100 \mu \mathrm{m})$, and a $40 \times$ objective lens with a 0.75 numerical aperture was used to count and measure individual cells within the counting frames. Every third section containing the MSN was evaluated and quantitative estimates of the total number and cell-soma size of ChAT-immunoreactive neurons in the MSN was calculated using this unbiased, stereological cell counting method [30, 31]. Cell volume was calculated using rotator probe stereological methods provided by the Bioquant software. Minimally, 100 cells were counted from each brain in a double-blind manner. The counting brick was $20-\mu \mathrm{m}$ thick. The analysis rendered a mean coefficient of error of $0.05-0.10$ as calculated according to Gundersen et al. [32]. An upper guard zone of $2 \mu \mathrm{m}$ was excluded from counting.

\section{Western blot analysis}

For western blot analyses, mice were euthanized and brains were immediately dissected and frozen on dry ice. Frozen hemibrains were homogenized as previously described using protease inhibitors [33], and proteins separated by $4-20 \%$ Tris-HCl SDSPAGE and transferred to polyvinylidene difluoride membranes. The anti-A $\beta P P$ C-terminal monoclonal antibody C1/6.1 $(1 \mu \mathrm{g} / \mathrm{ml})$ recognizes both mouse and human APP holoprotein and C-terminal fragments (CTFs) [25, 33, 34]. Membranes were incubated overnight in primary antibody, washed, and incubated with horseradish peroxidase-conjugated goat anti-mouse IgG (MP Biomedicals, Irvine, CA; dilution $1: 5000$ ) for $1 \mathrm{~h}$. ECL substrate (Amersham Biosciences, Piscataway, NJ) was added before exposure to $\mathrm{x}$-ray film. The membrane was then stripped and reprobed with anti- $\beta$-tubulin antibody (Abcam, Cambridge, MA; dilution 1:5000) as a loading control. Blots were quantified using Image $(\mathrm{NIH}, \mathrm{USA})$ and the density of signal was normalized against $\beta$-tubulin.

\section{Statistical analysis}

One-way analysis of variance (ANOVA), followed by posthoc multiple comparison using Dunnett's test, was used to evaluate the differences between genotypes. Error bars represent standard error of the mean.

\section{RESULTS}

\section{A $\beta P P$ overexpressing transgenic mouse models have altered early endosome morphology}

We labeled mouse brain tissue with an antibody against the small GTPase rab5b, a regulator of endocytosis and early endosome fusion and a specific marker for early endosomes [6]. Rab5b-positive early 
endosomes in frontoparietal cortical neurons from APP23 mice (middle panel, top row, Fig. 1A) and APPLd2 mice (right panel, top row, Fig. 1A) appeared abnormally large compared to the neurons from wt mice (left panel, top row, Fig. 1A), consistent with previous findings that early endosomal abnormalities in non-neuronal cells can be AßPP-dependent [7]. Rabaptin-5, which is an effector-protein of rab5, has also been used by our group to characterize early endosomes in brain tissue [6]. We found a robust increase in the expression of rabaptin-5 in both APP23 (middle panel, bottom row, Fig. 1A) and APPLd2 mice (right panel, bottom row, Fig. 1A) when compared to wt mice (left panel, bottom row, Fig. 1A).

Rab5b-immunolabelling of early endosomes in randomly chosen cortical neurons was quantitated, with the average size of individual endosomes compared among the three genotypes. Early endosomes in APP23 mice were found to be $2.42 \pm 0.50(p<0.01)$ times the average size of rab5b-positive endosomes in wt mice (Fig. 1B), while APPLd2 mice showed a non-significant trend toward increased average early endosomal size (1.52 \pm 0.31 times wt) (Fig. 1B).

\section{A $\beta P P$ expression and early endosomal morphology in BFCNs in the MSN of APP23 and APPLd2 mice}

Robust global overexpression of A $\beta P P$ and A $\beta P P$ CTFs in both APP23 and APPLd 2 mice was seen by western blot from hemibrain homogenates of 12month-old mice, with holoprotein levels greater in the APPLd2 mouse (Fig. 1C, D). As predicted given the $\beta$ cleavage promoting Swedish mutation expressed in the APP23 mouse [35], the increase in $\beta C T F$ levels was found to be greatest in this line (Fig. 1C, E). The more marked endosomal changes in the APP23 model are in agreement with the idea that $\beta C$ TFs are the primary mediators of A $\beta P P$-driven endosome disruption [7]. In order to examine A $\beta P P$ - and A $\beta P P$ metabolite-driven endosomal changes in cholinergic neurons of the MSN, we first confirmed that human $\mathrm{A} \beta \mathrm{PP}$ is overexpressed in cholinergic neurons of the transgenic mice by double immunolabeling with antibodies against human $\mathrm{A} \beta \mathrm{PP} / \beta \mathrm{CTF} / \mathrm{A} \beta$ (6E10; Fig. $2 \mathrm{~A})$ or human and murine $\mathrm{A} \beta \mathrm{PP} / \mathrm{CTFs}(\alpha \mathrm{CTF}+\beta \mathrm{CTF})$ but not $\mathrm{A} \beta(\mathrm{C} 1 / 6.1$; Fig. 2B). Both APP23 (middle panels, Fig. 2A, B) and APPLd2 (bottom panels, Fig. 2A, B) showed robust human A $\beta P P$ expression in cells of the MSN, including ChAT-positive cholinergic neurons. That both antibodies showed a similar cellular immunolabeling pattern confirms that BFCNs overexpress A $\beta P P$ in both transgenic models and that the immuno-signal is not only due to $A \beta$ immunoreactivity.

Changes in endosomal morphology in these BFCNs were demonstrated by double immunolabeling with antibodies against rab5b and ChAT (Fig. 3A). As we did for cortical neurons, we compared the size of rab5bpositive endosomes in ChAT-positive MSN cholinergic cells. Cholinergic early endosomal size in APP23 mice was significantly increased when compared to wt $(1.42 \pm 0.12 \%$ increase over wt, $p<0.05)$, while APPLd 2 again showed a non-significant trend toward an increase in early endosomal size $(1.2 \pm 0.08 \%$ increase over wt) (Fig. 3B).

\section{Cholinergic neuron loss in the MSN of APP23 and APPLd2 mice}

We next examined the morphology of cholinergic neurons and fibers in the MSN. Compared to wt ChATpositive cells, ChAT-positive cells in both APP23 and APPLd2 displayed dystrophic neurites, with fiber deafferentation and retracted neurites (Fig. 4A). Additionally, ChAT-positive cells in A $\beta P P$ transgenic mice were pyknotic compared to wt mice ChAT-positive cells (Fig. 4A). Using quantitative unbiased stereology, we found that both APP23 and APPLd2 mice $(n=7$ and $n=8$, respectively) had significantly fewer ChATpositive cells in the MSN $(3,119 \pm 122 ; 2,716 \pm 422$, respectively) compared to wt mice $(n=6 ; 4,293 \pm 402$; $p<0.05$ for both transgenic lines) (Fig. 4B). BFCNs in APP23 mice also exhibited smaller average cell soma volume $\left(1,107 \pm 26 \mu \mathrm{m}^{3}\right)$ when compared to wt mice $\left(1,542 \pm 136 \mu \mathrm{m}^{3} ; p<0.01\right)$, whereas APPLd2 mice $(n=8)$ did not show a similar atrophy in BFCN soma size $\left(1,598 \pm 96 \mu \mathrm{m}^{3}\right)$ (Fig. 4C).

\section{DISCUSSION}

We have examined two mouse models with neuronal $A \beta P P$ overexpression to assess neuronal early endosome morphology, finding that the $\beta C T F$ accumulating APP23 model, and to a lesser extent the APPLd2 mouse, develops early endosomal alterations that closely resemble those seen early in the pathogenesis of the disease in AD patients $[1,36,37]$. Similar to the human studies in which neuronal endosome changes were characterized in $\mathrm{AD}$ patients prior to florid plaque deposition [1, 36, 37], our studies parallel the human AD findings in that the APP23 and APPLd 2 mice have limited $A \beta$ deposition at 12 months of age $[35,38]$, yet show early endosomal pathology. Our group and others have used DS systems, both in vitro and in vivo, 

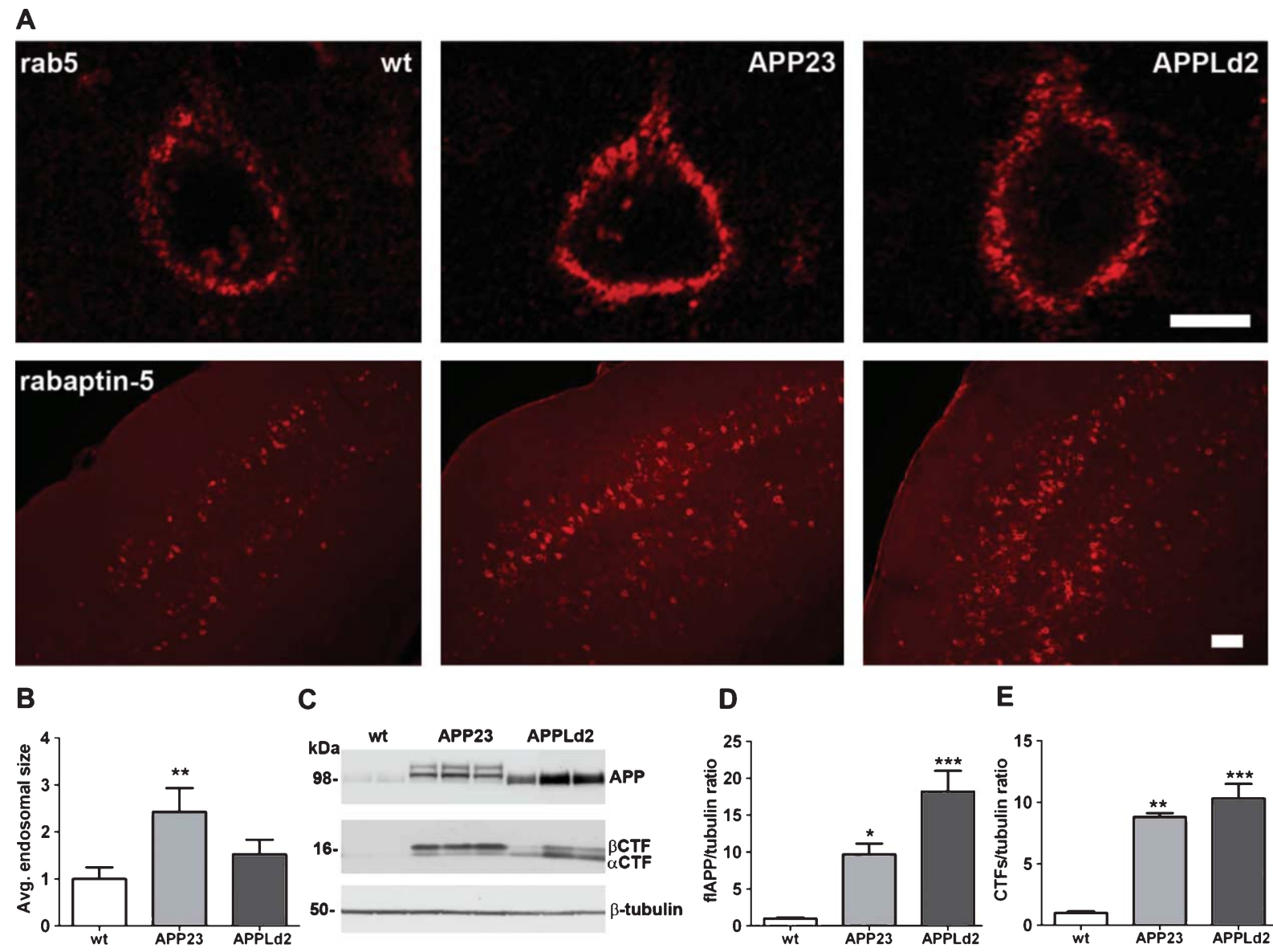

E

Fig. 1. The morphology of early endosomes is altered in $\mathrm{A} \beta \mathrm{PP}$ overexpressing transgenic mice. (A) Neurons from the frontoparietal cortex of APP23 (middle panel) and APPLd2 (right panel) mice labeled with rab5b (top row) and rabaptin-5 (bottom row) show enlarged endosomes and increased immunoreactivity compared to age-matched wt controls (left panel). As described in the Materials and Methods section, quantitation of average rab5b-positive early endosome size in APP23 and APPLd2 compared with wt mice is shown in (B). Measurements were made from 10-12 neurons per section, 3 sections per mouse, and 4 mice per genotype. Labeling conditions and exposure times were identical throughout. (C) Western blot of proteins from hemibrains lacking cerebella of wt, APP23, and APPLd2 mice probed with an anti-A $\beta$ PP C-terminal monoclonal antibody (C1/6.1), which detects both murine and human $\mathrm{A} \beta \mathrm{PP}$ and $\mathrm{CTFs}$ (upper and middle panels). $\beta$-tubulin reactivity is shown as a loading control (lower panel). Quantification of A $\beta P P(D)$ and CTF (E) band density (arbitrary units normalized to the $\beta$-tubulin bands, mean \pm SEM). Scale bars, top row $10 \mu \mathrm{m}$, bottom row $100 \mu \mathrm{m}$. Differences from wt were significant at $* p<0.05,{ }^{* *} p<0.01$, and $* * * p<0.001$.

as a model of AD-related early endosomal changes in addition to studying DS pathobiology [6-8, 39]. In murine DS models, A $\beta$ accumulation does not occur but endosomal disruption is prominent [7, 33]. While A $\beta P P$ overexpression appears to be a necessary contributor to endosomal alterations in these in vivo and in vitro DS models [7, 39, 40], it has not been previously shown in neurons that early endosomal alterations can be driven solely by A $\beta P P$ overexpression without the contributing effects from other DS-region triplicated genes. Indeed, our earlier study of brain A $\beta P P$ expression in the Ts65Dn mouse model shows that endosomal alterations occur prior to an increase in A $\beta P P$ mRNA and protein levels in the whole brain $[6,33]$, suggesting that DS trisomic cells may be particularly vulnerable to early endosomal disruption. Our findings disassociate the role of DS-related triplication of genes to endosomal abnormalities previously described; arguing instead that sufficient overexpression of $\mathrm{A} \beta \mathrm{PP}$ can drive neuronal early endosomal changes in vivo, thus extending this pathological alteration to commonly used AD mouse models.

Recent cell culture studies have directly implicated the cell-associated $\beta C T F$ of A $\beta P P$ in the development of endosomal pathology in cultured non-neuronal cells, including a $\beta$-cleavage-dependence in DS cells for this endosomal phenotype [7]. The greater endosomal pathology seen in the APP23 mouse as compared 
A
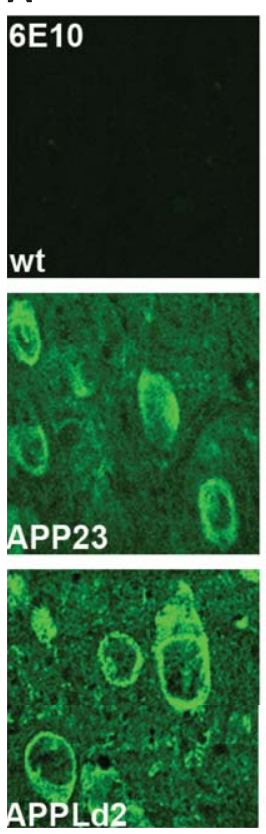
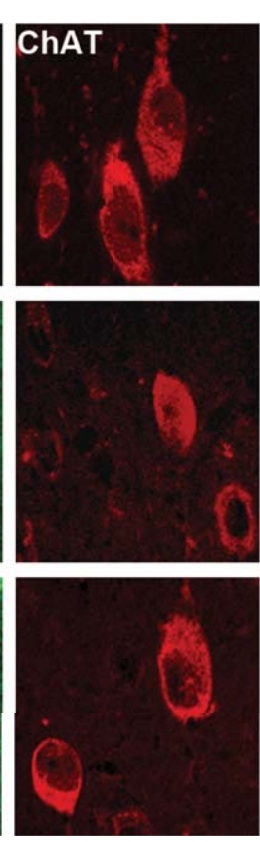
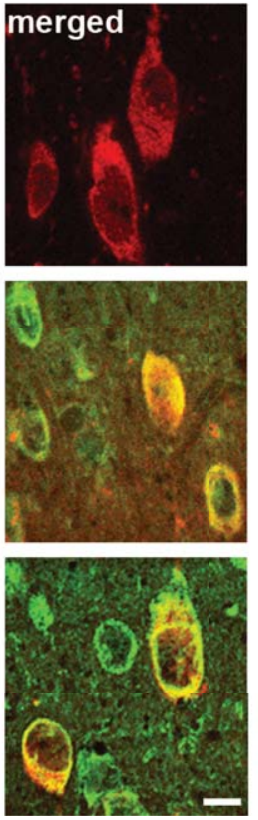

B
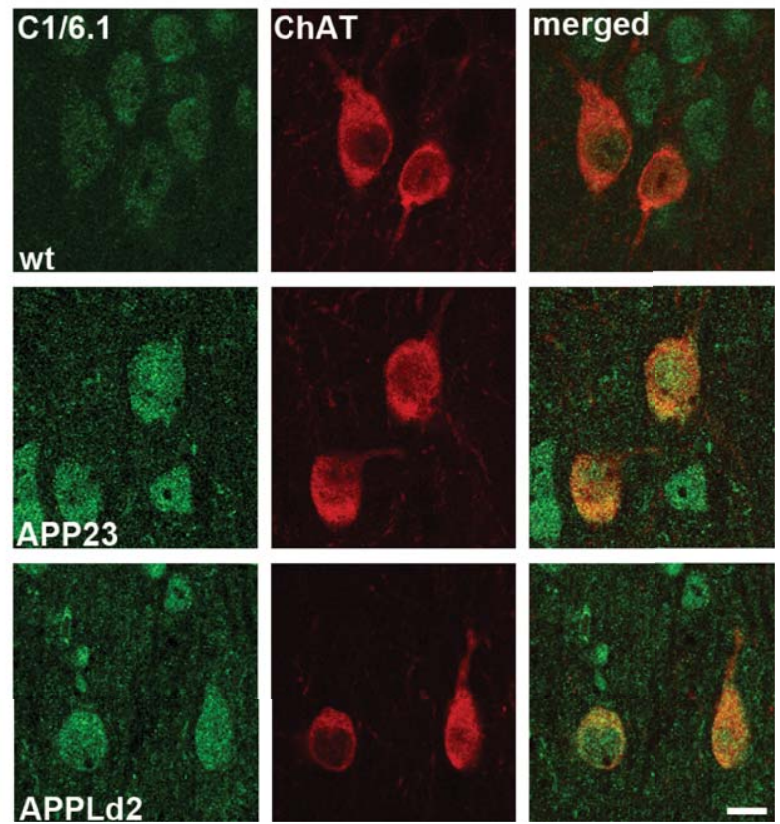

Fig. 2. Basal forebrain cholinergic neurons from APP23 and APPLd2 mice overexpress human A $3 P P$. A) Co-immunolabeling for ChAT (red) and antibody $6 \mathrm{E} 10$ (green), which reacts with human A $\beta P P, \beta C T F s$, and A $\beta$, in the MSN of APP23 (middle panels) and APPLd2 (bottom panels) mouse brain tissue. No 6E10 immunolabeling is seen in the wt mice (top panels). B) Co-immunolabeling for ChAT (red) and antibody $\mathrm{C} 1 / 6.1$ (green) [25], which reacts with human and murine A $\beta P P / \alpha C T F / \beta C T F$, in the MSN of APP23 (middle panels) and APPLd2 (bottom panels). Endogenous murine AßPP labeling is seen in the wt mouse tissue (top panels). Scale bars $100 \mu \mathrm{m}$.

to APPLd2 mice correlates with the robust expression of $\beta C T F s$ in this model. Although the possibility cannot be ruled out that early $A \beta$ deposition also affects neuronal endocytosis, previous evidence has shown that endosome pathology is not $\mathrm{A} \beta$-dependent both in vitro [7] and in vivo in BFCNs of a DS mouse model [39], strongly suggesting that A $\beta P P$ and cellassociated A $\beta P P$ metabolite levels contribute to early endosomal disruption.

The loss of BFCN and deficiencies in ChAT cholinergic enzyme activities in the pathogenesis of both DS and AD make this subpopulation of neurons of particular interest [15, 41-44]. Of varying severity and magnitude depending, in part, on age and brain region, many A $\beta P P$ overexpressing mouse models have been shown to exhibit cholinergic deficits, including APP23 [26, 28], APPLd2 [27], TgCRND8 [45], Tg2576 [46], PDAPP [47], PDAPP(Sw,Ind) [48], and APP/PS1KI [49] mice. In addition to dystrophic neurites, we demonstrate a significant loss of cholinergic cells in the MSN of APP23 and APPLd2 mice that parallels the findings in the brains of DS and AD patients [15, 41]. Others have attributed this cholinergic fiber loss with $A \beta$ load $[50,51]$, and it had been postulated that cortical cholinergic deficit in APP23 mice is a locally induced phenomenon driven by $\mathrm{A} \beta$ deposition in the MSN [26]. Our findings suggest an alternative and additional explanation consistent with the DS mouse model, that this vulnerable neuronal population has altered early endosomes in A $\beta P P$ overexpressing mice. These neurons have long projections into the hippocampus and cortex of the brain, and are dependent on retrograde trophic signaling to maintain cell viability and phenotype $[14,20,22]$. In this population, signaling endosomes mediate axon-to-cell-soma transport of nerve growth factor (NGF), and studies in a mouse model of DS have shown that abnormalities in these "signaling" endosomes that compromise NGF transport are App-dosage dependent [6, 39]. Our findings provide further support for the idea that altered endocytosis is a mechanism by which BFCNs degenerate in A $\beta P P$ overexpression mouse models. Consistent with a key role for the $\beta C T F$ in driving early endosomal changes [28], the APP23 mouse with the $\beta C$ TF-generation promoting Swedish mutation has greater neuronal early endosome alterations and BFCN pathology, with significantly reduced cholinergic cell volume compared to the APPLd2 mouse.

The vast majority of AD cases are sporadic and lateonset [52], and while increased expression of A $\beta P P$ 
A
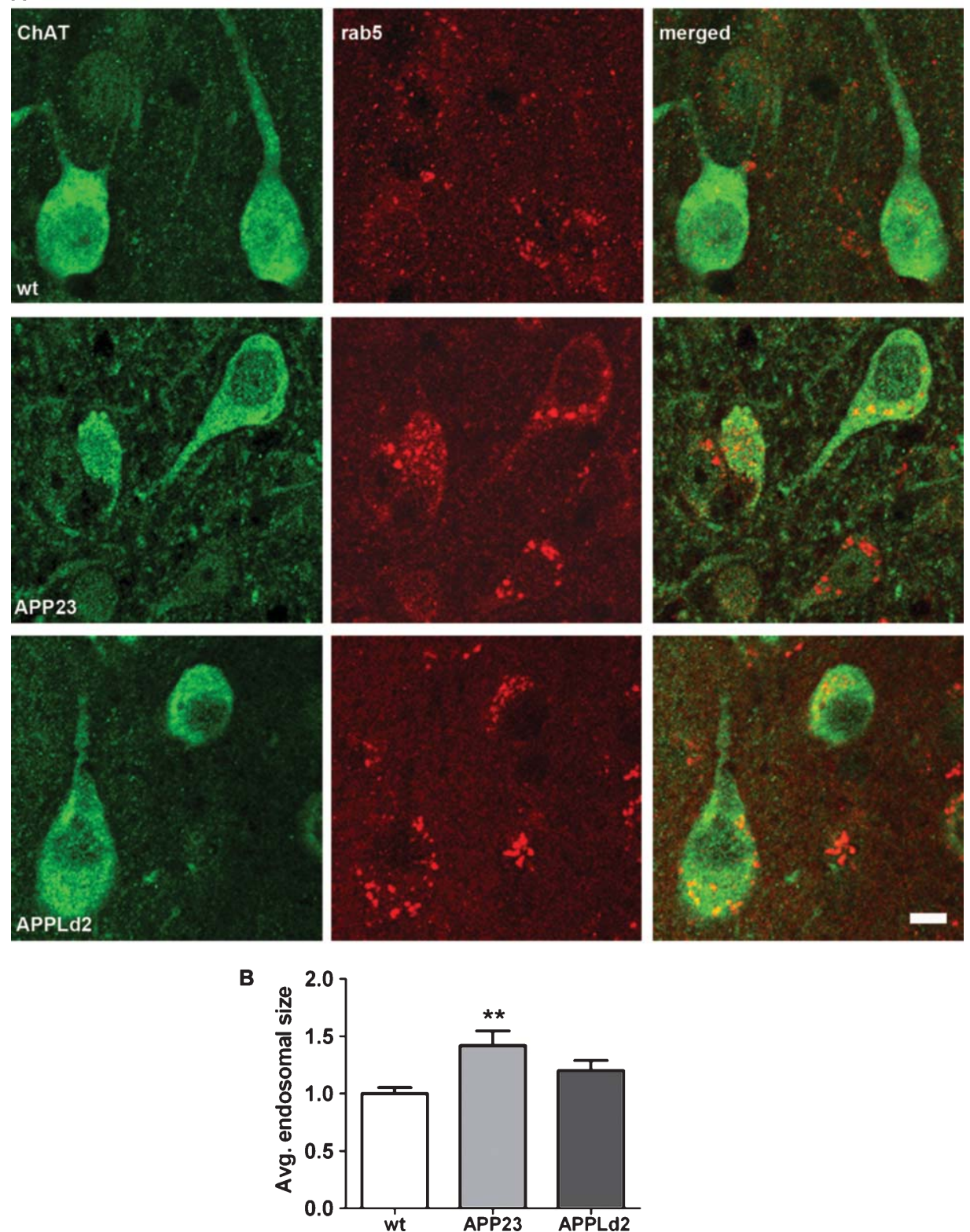

Fig. 3. Early endosomal disruption in basal forebrain cholinergic neurons. A) BFCNs in the MSN of APP23 and APPLd2 mice were identified using an antibody against ChAT (green), with rab5b immunolabeling used to show early endosomal morphology (red). Quantitation of average endosome size, as described in the Materials and Methods section, is depicted in (B) (average endosome size \pm SEM). Individual endosome area from a minimum of 100 cholinergic neurons per genotype was measured ( $n=4$ each genotype). Labeling conditions and exposure times were identical throughout. Scale bar, $10 \mu \mathrm{m}$. Differences from wt were significant at $* * p<0.01$.

has been suggested to be a contributing factor to the development of sporadic AD [53, 54], extensive overexpression of $\mathrm{A} \beta \mathrm{PP}$, as occurs in the $\mathrm{A} \beta \mathrm{PP}$ transgenic mice and with aging in the DS mouse models [13], is unlikely in the sporadic human disease. Nevertheless, endocytosis-dependent synaptic activity has been shown to increase $A \beta$ production, apparently by promoting $\beta C T F$ generation $[55,56]$. Other risk factors for late-onset $\mathrm{AD}$, such as altered lipid levels, may similarly increase the generation of $\beta C$ TFs within neurons $[2,3,57]$, suggesting that multiple mechanisms relevant to $\mathrm{AD}$ pathogenesis and $\mathrm{A} \beta$ production may concurrently increase cellular $\beta C$ TF levels. While the increase in neuronal $\beta C T F$ levels due to such 


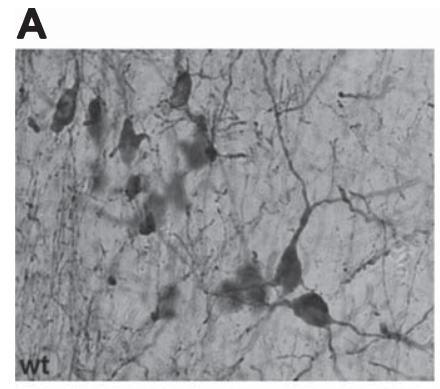

B

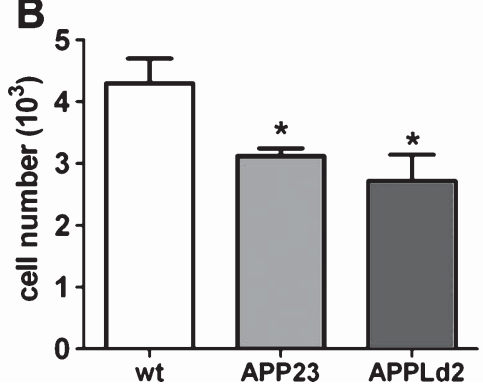

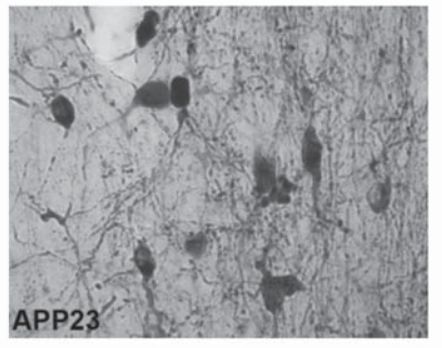

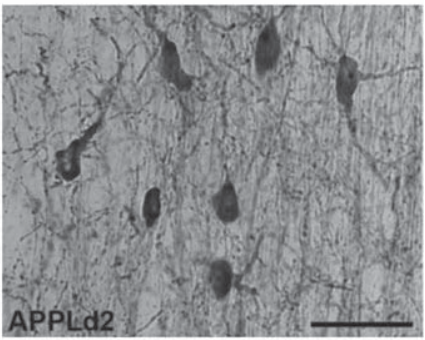

C

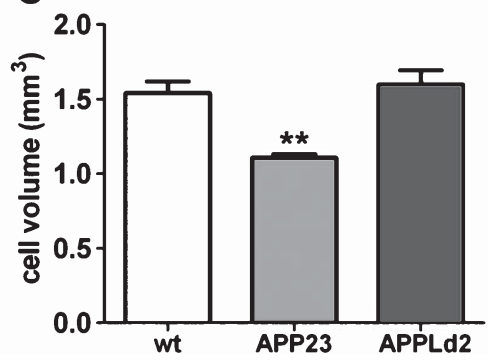

Fig. 4. Cholinergic neuron degeneration in the MSN of APP23 and APPLd2 mice. A) ChAT-immuno-positive neurons in the MSN of APP23 (middle panel, $n=7$ ) and APPLd2 (right panel, $n=8$ ) show fiber deafferentation and retracted neurites compared to age-matched wt controls (left panel, $n=6$ ). Unbiased stereological quantitation of ChAT-immuno-positive cell number (B) and cell-soma volume (C) are depicted (cell number \pm SEM; mean volume \pm SEM) (wt, $n=6$; APP23, $n=7$; APPLd2, $n=8$ ). Scale bar, $50 \mu m$. Differences from wt were significant at $* p<0.05 ; * * p<0.01$.

sporadic-risk factors may be moderate, prior findings in the DS model argues that limited changes in A $\beta P P$ levels are sufficient to lead to robust and pathologically significant early endosomal changes [7], presumably because of the vulnerability of the cells to these changes in the trisomic background. The overlaying of multiple factors in $\mathrm{AD}$ that are capable of altering endocytic function, including the direct impact of lipids and cholesterol, genetic vulnerabilities, and perhaps aging, can all contribute to an endocytic system that is poised to disruption by moderate changes in $\beta C T F$ levels. Abnormal endocytic function is likely to have many pathological consequences for neurons [23, 24], and the growing consistency that such changes are detected in multiple cell types and multiple models in which A $\beta P P$ and $\beta C T F$ expression is increased highlights the importance of $\mathrm{A} \beta \mathrm{PP}$ and its processing to this system.

\section{ACKNOWLEDGMENTS}

We thank Mr. Jay Fajiculay, Mr. Jason Berger, and Mrs. Anne Boyer-Boiteau for technical and research support, and Dr. Monika Pawlik for her maintenance of the mouse colonies. We are grateful to Dr. Matthias Staufenbiel and Dr. Fred Van Leuven for the kind gifts of the APP23 and APPLd2 transgenic mice respectively. This work was supported by the Alzheimer's Association (IIRG-07-60047, PMM) and the National Institutes of Health (5P01AG017617, PMM and EL; 5F31AG029787, JHKC).

Authors' disclosures available online (http://www.jalz.com/disclosures/view.php?id=1593) .

\section{REFERENCES}

[1] Cataldo AM, Peterhoff CM, Troncoso JC, Gomez-Isla T, Hyman BT, Nixon RA (2000) Endocytic pathway abnormalities precede amyloid $\beta$ deposition in sporadic Alzheimer's disease and Down syndrome: Differential effects of APOE genotype and presenilin mutations. Am J Pathol 157, 277286.

[2] Di Paolo G, Kim TW (2011) Linking lipids to Alzheimer's disease: Cholesterol and beyond. Nat Rev Neurosci 12, 284296.

[3] Burns MP, Rebeck GW (2010) Intracellular cholesterol homeostasis and amyloid precursor protein processing. Biochim Biophys Acta 1801, 853-859.

[4] Liu JP, Tang Y, Zhou S, Toh BH, McLean C, Li H (2010) Cholesterol involvement in the pathogenesis of neurodegenerative diseases. Mol Cell Neurosci 43, 33-42.

[5] Rogaeva E, Kawarai T, George-Hyslop PS (2006) Genetic complexity of Alzheimer's disease: Successes and challenges. J Alzheimers Dis 9, 381-387.

[6] Cataldo AM, Petanceska S, Peterhoff CM, Terio NB, Epstein CJ, Villar A, Carlson EJ, Staufenbiel M, Nixon RA (2003) App gene dosage modulates endosomal abnormalities of 
Alzheimer's disease in a segmental trisomy 16 mouse model of down syndrome. J Neurosci 23, 6788-6792.

[7] Jiang Y, Mullaney KA, Peterhoff CM, Che S, Schmidt SD, Boyer-Boiteau A, Ginsberg SD, Cataldo AM, Mathews PM, Nixon RA (2010) Alzheimer's-related endosome dysfunction in Down syndrome is $\mathrm{A} \beta$-independent but requires APP and is reversed by BACE-1 inhibition. Proc Natl Acad Sci U S A 107, 1630-1635.

[8] Cataldo AM, Mathews PM, Boiteau AB, Hassinger LC, Peterhoff CM, Jiang Y, Mullaney K, Neve RL, Gruenberg J, Nixon RA (2008) Down syndrome fibroblast model of Alzheimer-related endosome pathology: Accelerated endocytosis promotes late endocytic defects. Am J Pathol 173, 370-384.

[9] Thomas RS, Lelos MJ, Good MA, Kidd EJ (2011) Clathrinmediated endocytic proteins are upregulated in the cortex of the Tg2576 mouse model of Alzheimer's disease-like amyloid pathology. Biochem Biophys Res Commun 415, 656-661.

[10] Goate AM (1998) Monogenetic determinants of Alzheimer's disease: APP mutations. Cell Mol Life Sci 54, 897-901.

[11] Mullan M, Crawford F, Axelman K, Houlden H, Lilius L, Winblad B, Lannfelt L (1992) A pathogenic mutation for probable Alzheimer's disease in the APP gene at the Nterminus of $\beta$-amyloid. Nat Genet 1, 345-347.

[12] Goate A, Chartier-Harlin MC, Mullan M, Brown J, Crawford F, Fidani L, Giuffra L, Haynes A, Irving N, James L, et al. (1991) Segregation of a missense mutation in the amyloid precursor protein gene with familial Alzheimer's disease. Nature 349, 704-706.

[13] Ginsberg SD, Mufson EJ, Alldred MJ, Counts SE, Wuu J, Nixon RA, Che S (2011) Upregulation of select rab GTPases in cholinergic basal forebrain neurons in mild cognitive impairment and Alzheimer's disease. J Chem Neuroanat 42, 102-110.

[14] Howe CL, Mobley WC (2004) Signaling endosome hypothesis: A cellular mechanism for long distance communication. J Neurobiol 58, 207-216.

[15] Whitehouse PJ, Price DL, Clark AW, Coyle JT, DeLong MR (1981) Alzheimer disease: Evidence for selective loss of cholinergic neurons in the nucleus basalis. Ann Neurol 10, 122-126.

[16] Mufson EJ, Counts SE, Perez SE, Ginsberg SD (2008) Cholinergic system during the progression of Alzheimer's disease: Therapeutic implications. Expert Rev Neurother 8, 17031718.

[17] Ginsberg SD, Che S, Wuu J, Counts SE, Mufson EJ (2006) Down regulation of trk but not p75NTR gene expression in single cholinergic basal forebrain neurons mark the progression of Alzheimer's disease. J Neurochem 97, 475-487.

[18] Mufson EJ, Ginsberg SD, Ikonomovic MD, DeKosky ST (2003) Human cholinergic basal forebrain: Chemoanatomy and neurologic dysfunction. J Chem Neuroanat 26, 233-242.

[19] Mufson EJ, Counts SE, Fahnestock M, Ginsberg SD (2007) Cholinotrophic molecular substrates of mild cognitive impairment in the elderly. Curr Alzheimer Res 4, 340-350.

[20] Wu C, Cui B, He L, Chen L, Mobley WC (2009) The coming of age of axonal neurotrophin signaling endosomes. $J$ Proteomics 72, 46-55.

[21] Beattie EC, Zhou J, Grimes ML, Bunnett NW, Howe CL, Mobley WC (1996) A signaling endosome hypothesis to explain NGF actions: Potential implications for neurodegeneration. Cold Spring Harb Symp Quant Biol 61, 389-406.

[22] Sofroniew MV, Howe CL, Mobley WC (2001) Nerve growth factor signaling, neuroprotection, and neural repair. Annu Rev Neurosci 24, 1217-1281.
[23] Nixon RA (2005) Endosome function and dysfunction in Alzheimer's disease and other neurodegenerative diseases. Neurobiol Aging 26, 373-382.

[24] Nixon RA, Cataldo AM, Mathews PM (2000) The endosomallysosomal system of neurons in Alzheimer's disease pathogenesis: A review. Neurochem Res 25, 1161-1172.

[25] Mathews PM, Jiang Y, Schmidt SD, Grbovic OM, Mercken M, Nixon RA (2002) Calpain activity regulates the cell surface distribution of amyloid precursor protein: Inhibition of calpains enhances endosomal generation of $\beta$-cleaved $\mathrm{C}$ terminal APP fragments. J Biol Chem 277, 36415-36424.

[26] Boncristiano S, Calhoun ME, Kelly PH, Pfeifer M, Bondolfi L, Stalder M, Phinney AL, Abramowski D, Sturchler-Pierrat C, Enz A, Sommer B, Staufenbiel M, Jucker M (2002) Cholinergic changes in the APP23 transgenic mouse model of cerebral amyloidosis. J Neurosci 22, 3234-3243.

[27] Bronfman FC, Moechars D, Van Leuven F (2000) Acetylcholinesterase-positive fiber deafferentation and cell shrinkage in the septohippocampal pathway of aged amyloid precursor protein london mutant transgenic mice. Neurobiol Dis 7, 152-168.

[28] Van Dam D, Marescau B, Engelborghs S, Cremers T, Mulder J, Staufenbiel M, De Deyn PP (2005) Analysis of cholinergic markers, biogenic amines, and amino acids in the CNS of two APP overexpression mouse models. Neurochem Int 46, 409-422.

[29] Kaur G, Mohan P, Pawlik M, DeRosa S, Fajiculay J, Che S, Grubb A, Ginsberg SD, Nixon RA, Levy E (2010) Cystatin C rescues degenerating neurons in a cystatin B-knockout mouse model of progressive myoclonus epilepsy. Am J Pathol 177, 2256-2267.

[30] Granholm AC, Ford KA, Hyde LA, Bimonte HA, Hunter CL, Nelson M, Albeck D, Sanders LA, Mufson EJ, Crnic LS (2002) Estrogen restores cognition and cholinergic phenotype in an animal model of Down syndrome. Physiol Behav 77, 371-385.

[31] West MJ (1993) New stereological methods for counting neurons. Neurobiol Aging 14, 275-285.

[32] Gundersen HJ, Bagger P, Bendtsen TF, Evans SM, Korbo L, Marcussen N, Moller A, Nielsen K, Nyengaard JR, Pakkenberg B, et al. (1988) The new stereological tools: Disector, fractionator, nucleator and point sampled intercepts and their use in pathological research and diagnosis. APMIS 96, 857881.

[33] Choi JH, Berger JD, Mazzella MJ, Morales-Corraliza J, Cataldo AM, Nixon RA, Ginsberg SD, Levy E, Mathews PM (2009) Age-dependent dysregulation of brain amyloid precursor protein in the Ts65Dn Down syndrome mouse model. J Neurochem 110, 1818-1827.

[34] Morales-Corraliza J, Mazzella MJ, Berger JD, Diaz NS, Choi JH, Levy E, Matsuoka Y, Planel E, Mathews PM (2009) In vivo turnover of tau and APP metabolites in the brains of wild-type and Tg2576 mice: Greater stability of sAPP in the $\beta$-amyloid depositing mice. PLoS One 4, e7134.

[35] Sturchler-Pierrat C, Abramowski D, Duke M, Wiederhold KH, Mistl C, Rothacher S, Ledermann B, Burki K, Frey P, Paganetti PA, Waridel C, Calhoun ME, Jucker M, Probst A, Staufenbiel M, Sommer B (1997) Two amyloid precursor protein transgenic mouse models with Alzheimer disease-like pathology. Proc Natl Acad Sci U S A 94, 13287-13292.

[36] Cataldo A, Rebeck GW, Ghetri B, Hulette C, Lippa C, Van Broeckhoven C, van Duijn C, Cras P, Bogdanovic N, Bird T, Peterhoff C, Nixon R (2001) Endocytic disturbances distinguish among subtypes of Alzheimer's disease and related disorders. Ann Neurol 50, 661-665. 
[37] Cataldo AM, Barnett JL, Pieroni C, Nixon RA (1997) Increased neuronal endocytosis and protease delivery to early endosomes in sporadic Alzheimer's disease: Neuropathologic evidence for a mechanism of increased $\beta$-amyloidogenesis. J Neurosci 17, 6142-6151.

[38] Moechars D, Dewachter I, Lorent K, Reverse D, Baekelandt V, Naidu A, Tesseur I, Spittaels K, Haute CV, Checler F, Godaux E, Cordell B, Van Leuven F (1999) Early phenotypic changes in transgenic mice that overexpress different mutants of amyloid precursor protein in brain. J Biol Chem 274, 6483-6492.

[39] Salehi A, Delcroix JD, Belichenko PV, Zhan K, Wu C, Valletta JS, Takimoto-Kimura R, Kleschevnikov AM, Sambamurti K, Chung PP, Xia W, Villar A, Campbell WA, Kulnane LS, Nixon RA, Lamb BT, Epstein CJ, Stokin GB, Goldstein LS, Mobley WC (2006) Increased App expression in a mouse model of Down's syndrome disrupts NGF transport and causes cholinergic neuron degeneration. Neuron 51, 29-42.

[40] Cooper JD, Salehi A, Delcroix JD, Howe CL, Belichenko PV, Chua-Couzens J, Kilbridge JF, Carlson EJ, Epstein CJ, Mobley WC (2001) Failed retrograde transport of NGF in a mouse model of Down's syndrome: Reversal of cholinergic neurodegenerative phenotypes following NGF infusion. Proc Natl Acad Sci U S A 98, 10439-10444.

[41] Davies P, Maloney AJ (1976) Selective loss of central cholinergic neurons in Alzheimer's disease. Lancet 2, 1403.

[42] Coyle JT, Price DL, DeLong MR (1983) Alzheimer's disease: A disorder of cortical cholinergic innervation. Science 219, 1184-1190.

[43] Perry EK, Johnson M, Kerwin JM, Piggott MA, Court JA, Shaw PJ, Ince PG, Brown A, Perry RH (1992) Convergent cholinergic activities in aging and Alzheimer's disease. $\mathrm{Neu}$ robiol Aging 13, 393-400.

[44] Granholm AC, Sanders LA, Crnic LS (2000) Loss of cholinergic phenotype in basal forebrain coincides with cognitive decline in a mouse model of Down's syndrome. Exp Neurol 161, 647-663.

[45] Bellucci A, Luccarini I, Scali C, Prosperi C, Giovannini MG, Pepeu G, Casamenti F (2006) Cholinergic dysfunction, neuronal damage and axonal loss in TgCRND8 mice. Neurobiol Dis 23, 260-272.

[46] Apelt J, Kumar A, Schliebs R (2002) Impairment of cholinergic neurotransmission in adult and aged transgenic Tg2576 mouse brain expressing the Swedish mutation of human $\beta$ amyloid precursor protein. Brain Res 953, 17-30.

[47] German DC, Yazdani U, Speciale SG, Pasbakhsh P, Games D, Liang CL (2003) Cholinergic neuropathology in a mouse model of Alzheimer's disease. J Comp Neurol 462, 371-381.

[48] Aucoin JS, Jiang P, Aznavour N, Tong XK, Buttini M, Descarries L, Hamel E (2005) Selective cholinergic denervation, independent from oxidative stress, in a mouse model of Alzheimer's disease. Neuroscience 132, 73-86.

[49] Christensen DZ, Bayer TA, Wirths O (2010) Intracellular Ass triggers neuron loss in the cholinergic system of the APP/PS1KI mouse model of Alzheimer's disease. Neurobiol Aging 31, 1153-1163.

[50] Kar S, Quirion R (2004) Amyloid $\beta$ peptides and central cholinergic neurons: Functional interrelationship and relevance to Alzheimer's disease pathology. Prog Brain Res 145 , 261-274.

[51] Geula C, Nagykery N, Nicholas A, Wu CK (2008) Cholinergic neuronal and axonal abnormalities are present early in aging and in Alzheimer disease. J Neuropathol Exp Neurol 67, 309318.

[52] Pericak-Vance MA, Haines JL (1995) Genetic susceptibility to Alzheimer disease. Trends Genet 11, 504-508.

[53] Rovelet-Lecrux A, Hannequin D, Raux G, Le Meur N, Laquerriere A, Vital A, Dumanchin C, Feuillette S, Brice A, Vercelletto M, Dubas F, Frebourg T, Campion D (2006) APP locus duplication causes autosomal dominant earlyonset Alzheimer disease with cerebral amyloid angiopathy. Nat Genet 38, 24-26.

[54] Sleegers K, Brouwers N, Gijselinck I, Theuns J, Goossens D, Wauters J, Del-Favero J, Cruts M, van Duijn CM, Van Broeckhoven C (2006) APP duplication is sufficient to cause early onset Alzheimer's dementia with cerebral amyloid angiopathy. Brain 129, 2977-2983.

[55] Cirrito JR, Kang JE, Lee J, Stewart FR, Verges DK, Silverio LM, Bu G, Mennerick S, Holtzman DM (2008) Endocytosis is required for synaptic activity-dependent release of amyloid- $\beta$ in vivo. Neuron 58, 42-51.

[56] Cirrito JR, Yamada KA, Finn MB, Sloviter RS, Bales KR, May PC, Schoepp DD, Paul SM, Mennerick S, Holtzman DM (2005) Synaptic activity regulates interstitial fluid amyloid- $\beta$ levels in vivo. Neuron 48, 913-922.

[57] Kalvodova L, Kahya N, Schwille P, Ehehalt R, Verkade P, Drechsel D, Simons K (2005) Lipids as modulators of proteolytic activity of BACE: Involvement of cholesterol, glycosphingolipids, and anionic phospholipids in vitro. J Biol Chem 280, 36815-36823. 